\title{
PENINGKATAN KEMAMPUAN MENULIS SURAT LAMARAN PEKERJAAN MELALUI METODE QUANTUM WRITING PADA SISWA SMA
}

\author{
Sudiyono \\ SMAN 1 Menjalin
}

\begin{abstract}
Abstrak
Tujuan penelitian ini untuk mengetahui gambaran peningkatan kemampuan menulis surat lamaran pekerjaan melalui metode Quantum Writing pada siswa Kelas XI Mia 1 SMAN 1 Menjalin. Jenis penelitian ini adalah penelitian tindakan kelas. Subjek dalam penelitian ini berjumlah 35 siswa yang dilaksanakan dalam 2 siklus. Teknik pengumpulan data terdiri dari observasi dan tes. Prosedur yang digunakan adalah (1) tahap perencanaan, (2) pelaksanaan, (3) observasi, (4) refleksi. Hasil penelitian ini menunjukkan dapat meningkatkan aktivitas belajar. hal ini dapat dilihat dari aktivitas guru pada siklus I diperoleh rata-rata 27,5 dengan kriteria "cukup" dan meningkat pada siklus II dengan rata-rata 34 dengan kriteria "baik". Pada aktivitas siswa pada siklus I diperoleh rata-rata 29 dengan kriteria "cukup" dan meningkat pada siklus II dengan skor rata-rata 32 dengan kriteria "baik". Hasil analisis ketuntasan belajar secara klasikal pada siklus I sebesar 50\% dengan nilai rata-rata 72,9. Pada siklus II ketuntasan belajar secara klasikal sebesar 75\% dengan nilai rata-rata 79,6. Berdasarkan data tersebut ketuntasan belajar klasikal mengalami peningkatan. Dengan demikian dapat disimpulkan bahwa penerapan metode Quantum Writing dapat meningkatkan aktivitas belajar dalam pembelajaran menulis surat lamaran pekerjaan siswa di kelas XII MIA 1 SMAN 1 Menjalin Kecamatan Menjalin Kabupaten Landak.
\end{abstract}

\section{Kata Kunci : Kemampuan Menulis, Surat Lamaran Pekerjaan, Metode Quantum Writing}

\section{PENDAHULUAN}

Dalam pembangunan nasional, pendidikan diartikan sebagai upaya meningkatkan harkat dan martabat manusia serta dituntut untuk menghasilkan kualitas manusia yang lebih tinggi untuk menjamin pelaksanaan dan kelangsungan pembangunan. Peningkatan kualitas pendidikan harus dipenuhi melalui peningkatan proses pembelajaran, metode pembelajaran, kesejahteraan pendidik dan tenaga kependidikan lainnya. Dalam upaya memperbaiki kualitas pendidikan agar relevan dengan perkembangan zaman dan kebutuhan siswa di masa yang akan datang, pemerintah perlu mengupayakan suatu pembaharuan terhadap sistem pendidikan. Pembaharuan sistem pendidikan dapat dilakukan salah satunya melalui peningkatan mutu mata pelajaran Bahasa Indonesia karena merupakan salah satu mata

pelajaran yang sangat penting di SMA yang saat ini telah berkembang pesat baik materi maupun kegunaannya. Hal ini perlu ditingkatkan, karena Bahasa Indonesia sebagai simbol persatuan dan sebagai bahasa resmi yang telah disepakati bersama oleh seluruh bangsa Indonesia. Melalui bahasa manusia mengetahui perkembangan ilmu pengetahuan dan teknologi yang sedang berlangsung. Mengingat pentingnya bahasa sebagai alat komunikasi, maka dalam proses pembelajaran Bahasa Indonesia di SMA juga harus diarahkan pada tercapainya keterampilan berkomunikasi, baik secara lisan maupun tertulis, dalam hal pemahaman dan penggunaan. Kemahiran bahasa lisan menekankan pada aspek bicara dan menyimak, sedangkan kemampuan bahasa tulis menekankan pada aspek menulis dan membaca. Sesuai dengan perkembangan 
Kurikulum 13 oleh pemerintah menghendaki terwujudnya suasana yang menarik agar siswa dapat mengembangkan potensi dirinya. Salah satu pembelajaran yang dapat mengembangkan potensi siswa adalah menulis surat karena surat merupakan suatu pernyataan tertulis maka pemakaian bahasa pada surat-menyurat sangat mempengaruhi informasi yang disampaikan. Khusus untuk pemakaian bahasa pada surat menyurat yang sifatnya resmi, maka penulisan harus sesuai dengan kaedah atau aturan yang berlaku dalam bahasa Indonesia. Menurut Tarigan (1994:1) keterampilan berbahasa mencakup empat aspek yaitu menyimak (listening Skill), Berbicara (Speking Skill), Membaca (Reading Skill) dan Menulis ( Writing Skill).

Penguasaan keempat aspek ini merupakan keterampilan dasar. Untuk menunjang keberhasilan tujuan umum pembelajaran bahasa Indonesia, maka siswa terampil dalam berbahasa yang mencakup aspek mendengarkan, berbicara, membaca, menulis dan apresiasi sastra. Keempat aspek keterampilan berbahasa tersebut, aspek keterampilan menulis merupakan aspek yang paling tinggi dan paling kompleks tingkatannya. Aspek keterampilan menulis jauh lebih sukar dan jauh lebih rumit dibandingkan aspek kebahasaan yang lainnya, seperti keterampilan menyimak, keterampilan berbicara, dan keterampilan membaca.

Menulis merupakan salah satu dari pokok bahasan bahasa Indonesia yang bertujuan memberikan bekal keterampilan dan kemampuan kepada siswa untuk mengkomunikasikan ide atau pesan. Menulis adalah kegiatan melahirkan pikiran dan perasaan dengan tulis menulis juga dapat diartikan sebagai cara berkomunikasi dengan mengungkapkan pikiran, perasaan, dan kehendak kepada orang lain secara tertulis Keterampilan menulis dianggap sebagai keterampilan yang sulit dan rumit tetapi keterampilan menulis itu sangatlah penting untuk dipelajari dan dilakukan terus menerus. Keterampilan menulis harus didukung juga oleh keterampilan lainnya terutama keterampilan membaca, karena membaca dan menulis saling berkaitan. Menurut maksud dan tujuannya surat dibagi menjadi empat macam surat yaitu: surat permohonan atau permintaan, surat keputusan, surat kuasa, dan surat lamaran.

Berdasarkan empat macam surat di atas, pelajaran menulis surat lamaran pekerjaan merupakan salah satu aspek pengajaran bahasa Indonesia yang pembelajarannya tidak difokuskan secara sungguh-sungguh, maka peneliti mengambil satu bentuk surat yang dijadikan penelitian yaitu surat lamaran pekerjaan karena dalam menulis surat lamaran pekerjaan siswa masih sangat sulit dalam menggunakan isi gagasan, pilihan kata, kalimat, paragraf, dan ejaan. Materi menulis surat lamaran pekerjaan ini diberikan pada siswa, untuk meningkatkan hasil belajar siswa perlu dilakukan berbagai upaya perbaikan, khususnya dalam proses pembelajaran diperlukan perencanaan, pelaksanaan, evaluasi serta pemilihan metode yang tepat. Dalam upaya meningkatkan hasil menulis surat lamaran pekerjaan siswa, penulis perlu melakukan inovasi kreatif, yaitu dengan cara menerapkan motode pembelajaran yang dapat menciptakan suasana yang menyenangkan bagi siswa, sehingga menimbulkan proses pembelajaran yang aktif.

Faktor internal terlihat pada kurang terampilnya siswa mempergunakan ejaan dan memilih kata sehingga penyusunan kalimat masih banyak mengalami kesalahan. Faktor eksternal muncul dari pemilihan strategi dan pendekatan yang digunakan guru. Guru masih terikat pada pola pembelajaran tradisional dan monoton. Kondisi seperti ini dapat menghambat para siswa untuk aktif dan kreatif sehingga menyebabkan rendahnya kualitas siswa. Sistem pembelajaran dengan pendekatan tradisional yang masih diterapkan guru tidak mampu menciptakan anak didik yang diidamkan, terutama untuk bidang keterampilan menulis. Hal ini dikarenakan dominasi guru dalam pembelajaran dengan pendekatan tradisional lebih menonjol dan dikuasai guru, sehingga keterlibatan siswa kurang mendapat tempat. Guru lebih banyak mendominasi sebagian besar aktivitas proses belajar-mengajar sehingga para siswa 
cenderung pasif. Jika keadaan tersebut terus berlanjut,tanpa ada solusi penanggulangannya secara tepat dikhawatirkan lama-kelamaan akan menurunkan kemampuan dan kualitas siswa dalam menulis. Pemilihan strategi dan pendekatan yang tepat dalam pembelajaran merupakan hal yang harus betul-betul dipertimbangkan oleh guru agar tujuan pembelajaran yang telah dirumuskan dapat mencapai sasaran.

Dalam meningkatkan partisipasi aktif fisik dan mental siswa, guru hendaknya tidak mendominasi aktivitas belajar-mengajar, tetapi memberikan kesempatan seluasluasnya pada siswa untuk berinteraksi dengan guru, dengan materi pelajaran maupun dengan sesama manusia. Demikian juga siswa hendaknya diberi kesempatan berlatih pada saat guru menyampaikan pelajaran yang berupa suatu keterampilan. Untuk itu agar pembelajaran menjadi menyenangkan dan hasil menulis surat lamaran pekerjaan siswa menjadi lebih aktif maka guru menerapkan metode pembelajaran Quantum Writing karena merupakan sebuah proses interaksi yang terjadi lewat proses menulis. Seseorang yang menjalankan konsep "Quantum writing", akan merasakan bahwa dirinya sedang berinteraksi dengan dirinya yang unik, materi tulisan yang sedang ditulisnya, dan dengan pikiran-pikiran orang lain yang telah dibicaranya sebelum dia menulis.Pembelajaran dengan metode Quantum Writing mempunyai tahap-tahap dalam proses pembelajaran dalam menulis, tahap-tahap tersebut, yaitu tahap persiapan, draft kasar, berbagi, revisi, penyuntingan, penulisan kembali, dan evaluasi. Menulis adalah suatu upaya memindahkan lisan ke wujud bahasa tulisan, dengan menggunakan lambang-lambnag grafem. (Sukino, 2010:5). Menulis adalah kegiatan melahirkan pikiran dan perasaan dengan tulis menulis juga dapat diartikan sebagai cara berkomunikasi dengan mengungkapkan pikiran, perasaan dan kehendak kepada orang lain secara tertulis. Menurut Susetyo (2009: 1), menulis adalah "kegiatan untuk melahirkan pikiran atau perasaan". Hasil yang dilahirkan oleh pikiran atau perasaan dalam bentuk tulis disebut tulisan atau karya tulis. Selanjutnya Deporter (2009: 179) menulis adalah " aktivitas seluruh otak yang menggunakan belahan otak yang menggunakan belahan otak kanan (emosional) dan belahan otak kiri (logika)"

Dengan demikian, menulis merupakan serangkaian kegiatan untuk mengemukakan suatu ide atau gagasan dalam bentuk lambang bahasa tulis agar dapat dibaca oleh orang lain. Dapat juga diartikan bahwa menulis adalah berkomunikasi mengungkapkan pikiran, perasaan, dan kehendak orang lain secara tertulis. Keterampilan menulis yang dimiliki oleh seseorang, bukanlah suatu proses yang otomatis yang dibawa sejak lahir melainkan diperoleh melalui tindak pembelajaran.

Jadi, keterampilan menulis adalah suatu kegiatan yang mengekspresikan gagasan atau ide yang mempunyai urutan yang logis dengan menggunakan bahasa tulis secara lisan yang lebih menekankan pada proses, pikiran, pengetahuan dan pengalaman. Menulis pada hakikatnya bertujuan membangun suatu sistem hubunganhubungan kemanusiaan yang diperluas, sistem tempat dia dan pembaca dalam beberapa hal bersatu, membagi ilmu pengetahuan, nilai-nilai, dan perspektifperspektif dalam suatu masyarakat, upaya retoris berbicara dan menyimak merupakan jembatan penghubung antara sesama anggota masyarakat, begitu juga antara penulis dan pembaca untuk mencapai komunikasi yang efektif dan dapat menuangkan ide, pikiran, pengetahuan, pengalaman hidup serta menggambarkan suatu benda atau peristiwa sehingga tercapainya komunikasi antara penulis dan pembaca.

Menurut Caca Sudarsa dkk (1992: 3) Surat merupakan suatu alat komunikasi tertulis yang digunakan untuk menyampaikan informasi tertentu kepada seseorang, badan, atau lembaga tertentu. Informasi yang disampaikan dapat berupa pemberitahuan, pernyataan, perintah, permintaan, atau laporan. Ferdinansyah (2007:29) menyatakan Surat adalah suatu sarana untuk menyampaikan informasi secara tertulis dari pihak yang satu kepada pihak yang lain. 
Informasi tersebut dapat berupa pemberitahuan, pernyataan, permintaan, laporan, dan sebagainya. lebih lanjut Soewito, dkk (1980: 8) menyatakan bahwa surat adalah suatu sarana untuk menyampaikan informasi atau pernyataan secara tertulis kepada pihak lain baik atas nama sendiri ataupun jabatannya dalam organisasi.

Berdasarkan definisi penulis di atas dapat disimpulkan bahwa surat merupakan suatu sarana komunikasi yang digunakan untuk menyampaikan informasi tertulis yang perlu diketahui orang tertentu atau suatu pernyataan yang harus direspon (dijawab atau dibalas) oleh penerimanya. Dengan kata lain, surat menyurat itu merupakan salah satu kegiatan berbahasa yang dilakukan dalam komunikasi tertulis.

Fungsi surat adalah merupakan alat komunikasi tertulis yang mempunyai kelebihan jika dibandingkan tertulis yang mempunyai kelebihan jika dibandingkan dengan alat komunikasi lain, yaitu biaya surat menyurat relatif lebih murah jika dibandingkan dengan biaya telepon. Surat dapat pula mengurangi kesalahpahaman dalam berkomunikasi, karena penulis dapat menyampaikan maksudnya dengan sejelasjelasnya. Oleh karena itu, fungsi utama surat adalah sebagai alat komunikasi tertulis. Surat selain sebagai alat komunikasi, surat juga mempunyai fungsi, seperti yang dikemukakan oleh (Caca Sudarsa dkk, 1992: 3) sebagai berikut: (a) Alat untuk menyampaikan pemberitahuan, permintaan atau permohonan buah pikiran atau gagasan, (b) Alat bukti tertulis, misalnya surat perjanjian, (c) Alat untuk mengingat, misalnya surat-surat yang diarsipkan, (d) Bukti historis, misalnya suratsurat yang bersejarah, (e) Pedoman kerja, misalnya surat keputusan dan surat perintah.

$$
\text { Caca Sudarsa dkk,(1992:9) }
$$

menyatakan bahwa unsur-unsur surat lamaran pekerjaan, yakni : “ (1) Kepala surat , (2) Tempat dan tanggal penulisan surat, (3) Salam pembuka, (4) Pembuka surat, (5) Tujuan surat lamaran pekerjaan, (6) Lampiran persyaratan yang ditentukan, (7) Penutup surat, (8) Tanda tangan dan nama jelas pelamar “
Sagala (2003:169) mengemukakan, metode pembelajaran adalah cara yang digunakan guru dalam mengorganisasikan kelas pada umumnya atau dalam menyajikan bahan pelajaran pada khususnya. Surakhmad (1979:75) mengemukakan metode adalah cara yang di dalam fungsinya merupakan alat untuk mencapai suatu tujuan. Berdasarkan definisi penulis diatas dapat disimpulkan bahwa metode pembelajaran merupakan suatu cara atau upaya yang dilakukan oleh para pendidik agar proses belajar-mengajar pada siswa tercapai sesuai dengan tujuan.

Metode pembelajaran kuantum (Quantum Learning and Teaching) dimulai di Super Camp, sebuah program percepatan berupa Quantum Writing yang ditawarkan Learning Forum, yaitu sebuah perusahaan pendidikan internasional yang menekankan perkembangan keterampilan akademis dan keterampilan pribadi (Deporter,1992). Selanjutnya Hernowo (2003: 10), mengatakan Bahwa Quantum adalah interaksi yang mengubah energi menjadi pancaran cahaya yang dahsyat.

Berdasarkan uraian di atas, dapat disimpulkan bahwa Quantum adalah bagian dari energi yang tidak dapat dipecahkan lagi sehingga dapat mengubah energi itu menjadi pancaran cahaya. Metode Quantum diciptakan berdasarkan teori pendidikan seperti Accelerated Learning (Lozanov), Multiple Intelegences (Gardner), Neuro Linguistic Programming (grinder dan Bandler), Experiential Learning (Hahn), Socratic Inguiry, Cooperative Learning (Johnson) dan Element of Effective Instruction (Hunter) menurut Suyatno (2004:28) Metode Quantum adalah pengubahan bermacam-macam interaksi yang ada di dalam dan di sekitar momen belajar, alamiah dengan secara sengaja menggunakan musik, mewarnai lingkungan sekeliling, menyusun bahan pengajaran yang sesuai.

Metode Quantum mencakup petunjuk spesifik untuk menciptakan lingkungan belajar yang efektif. Merancang kurikulum, menyampaikan isi dan memudahkan proses belajar. Asas yang digunakan adalah bawalah dunia mereka ke dunia kita dan antarlah dunia 
kita ke dunia mereka. Menurut Deporter (2009:18), Bahwa Quantum sebagai "interaksi yang mengubah energi menjadi cahaya". Hal ini berarti mampu merasakan dalam diri aliran cahaya keberadaan yang terjadi jika semua energi disalurkan menuju solusi-solusi yang berhasil.

Tujuan Pembelajaran Quantum Writing menurut Hernowo (2003: 52) adalah “(1) Memunculkan sisi-sisi unik yang dimilikinya dan kemudian perlahan lahan dapat dikenalinya secara utuh, (2) Diharapkan dapat memberikan kebaruan tentang menulis, (3) Memunculkan penulis agar dirinya siap dan berani untuk menulis, (4) Untuk memperkaya mental seorang penulis"

Berdasarkan uraian di atas dapat disimpulkan bahwa tujuan pembelajaran Quantum Writing adalah untuk memunculkan kemampuan menulis serta mengembangkannya sehingga 35 siswa memiliki kesiapan mental untuk menulis surat dan siswa mempunyai pembaharuan pengetahuan tentang menulis surat.

Langkah-langkah Pembelajaran Quantum Writing menurut Bobbi De Porter dan Hernacki Mike mengungkap bahwa untuk melangkah ke proses penulisan seutuhnya maka tahap-tahap yang perlu ditentukan adalah : (1) Persiapan yaitu pengelompokan (clustering) menentukan jenis surat khususnya surat lamaran pekerjaan pada tahap ini hanya membangun suatu fondasi yang berdasarkan pada pengetahuan, gagasan dan pengalaman (2) Draft Kasar, pada tahap ini mulai menekuni dan mengembangkan gagasan-gagasan. Pusatkan dulu pada isi surat lamaran pekerjaan sebelum melangkah ke tata bahasa atau ejaan. Pada tahap ini mulai menerapkan jenis-jenis surat khususnya memberitahukan menjadi surat lamaran pekerjaan, (3) Berbagi, yaitu bagian proses ini sebagai penulis kita merasa sangat dekat dengan tulisan kita sehingga sulit bagi kita untuk menilai secara objektif. Untuk mengambil jarak dengan tulisan maka perlu meminta orang lain dan memberi umpan balik. (saling bertukar hasil tulisan), (4) Memperbaiki (Revisi), pada tahap ini setelah mendapat umpan balik tentang tulisan mana yang baik dan mana yang perlu digarap lagi. Memanfaatkan umpan balik yang dapat memperbaiki hasil tulisan kita (memperbaiki hasil tulisan), (5) Penyuntingan, pada tahap ini perbaikilah semua kesalahan isi, diksi, kalimat, paragraf, dan ejaan, (6) penulisan Kembali, pada tahap ini tulis kembali dan masukan isi yang baru dan perubahan penyuntingan, (7) Evaluasi, pada tahap ini, penulis memeriksa semua tulisannya dan memperbaiki semua tulisan apa ejaannya sudah tepat atau belum dan diakhiri dengan mengadakan perayaan pembelajaran dengan bernyanyi bersama. Suatu pembelajaran khususnya pembelajaran bahasa Indonesia akan lebih bermakna jika guru mampu menciptakan suasana belajar yang dapat membuat siswa aktif, pikirannya kreatif, dan membuatnya merasa senang mengikuti proses pembelajaran tersebut adalah dengan menerapkan metode Quantum Writing.

\section{METODE PENELITIAN}

Setting dalam penelitian ini meliputi: (1) Subjek dan Objek penelitian, (2) Waktu Penelitian, (3) Siklus Penelitian Tindakan Kelas, (4) Sumber Data, (5) Teknik dan alat pengumpul data sebagai berikut: a) Subjek dan Objek Penelitian adalah siswa kelas XII Mia 1 SMAN 1 Menjalin Kabupaten Landak yang berjumlah 35 orang, b) waktu penelitian tindakan kelas ini dilaksanakan pada semester genap di Kelas XII Mia 1 SMAN 1 Menjalin Kabupaten Landak, c) Penelitian dilaksanakan melalui dua siklus, dalam satu siklus terdiri dari dua kali pertemuan d) Sumber data adalah lembar observasi aktivitas guru terdapat 13 butir pertanyaan dan pengukuran skala penilaian pada proses observasi guru yaitu antara 1 sampai 3, e) Teknik dan alat pengumpul yaitu (1) Teknik observasi adalah teknik penilaian dengan cara mengadakan pengamatan terhadap suatu hal secara langsung, teliti dan sistematis (Nurgiyantoro, 2001 : 57). Observasi terdiri dari lembar obsernasi guru dan siswa yang digunakan untuk mengamati keadaan siswa, keaktifan siswa dan sikap siswa selama mengikuti proses pembelajaran serta bagaimana guru mengelola pembelajaran. 
Prosedur penelitian adalah suatu rangkaian tahap-tahap penelitian dari awal sampai akhir. Penelitian ini merupakan proses pengkajian sistem berdaur sebagaimana kerangka berpikir yang dikembangkan oleh Suharsimi Arikunto dkk (2006;74). Prosedur ini mencakup tahap-tahap: (1) perencanaan , (2) Pelaksanaan, (3) pengamatan, dan (4) Refleksi. Keempat kegiatan tersebut saling terkait dan secara urut membentuk sebuah siklus. Penelitian yang bersiklus, artinya penelitian dilakukan secara berulang dan berkelanjutan sampai tujuan penelitian dapat tercapai.

\section{HASIL DAN PEMBAHASAN}

Berdasarkan hasil pelaksanaan pembelajaran dua siklus, terdapat data yang mengalami peningkatan. Metode Quantum writing dalam menulis surat lamaran pekerjaan dapat meningkatkan proses pembelajaran dan hasil tes siswa kelas XII Mia 1.

Pembelajaran dengan metode Quantum Writing di kelas selama siklus I dan II ini, ditujukan dengan membangkitkan semangat siswa, seperti memberikan sebuah contoh surat lamaran pekerjaan, dari sebuah contoh surat lamaran pekerjaan tersebut timbullah pertanyaan-pertanyaan yang membangkitkan imajinasi siswa, memancing siswa untuk dapat berbicara di depan temanteman, dan dapat menulis surat lamaran pekerjaan berdasarkan pertanyaan-pertanyaan dan memperhatikan EYD.

Hasil analisis data berdasarkan siklus I yang diikuti 35 siswa, didapat nilai rata-rata 72,9 dan ketuntasan belajar klasikal 50\%. Jumlah yang tuntas sebanyak 25 siswa, sedangkan yang belum tuntas sebanyak 10 siswa, hal ini menunjukkan bahwa siklus I belum memenuhi kriteria kelulusan. Karena belum mencapai 75 . Pada siklus II yang diikuti 35 siswa, hasilnya meningkat dengan rata-rata sebesar 79,6 dan ketuntasan belajar klasikal $75 \%$. Jumlah siswa yang tuntas di siklus II sebesar 25 siswa.

Berdasarkan perbandingan nilai siklus I dan II terdapat perbedaan hasil yakni pada tingkat penguasaan sangat baik pada siklus I tidak ada sedangkan pada siklus II sebanyak 10 siswa. Tingkat penguasaan baik pada siklus I sebanyak 20 siswa, sedangkan pada siklus II sebanyak 15 siswa. Tingkat penguasaan cukup siklus I sebanyak 15 dan pada siklus II sebanyak 10 siswa. Peningkatan nilai rata-rata dari siklus I dan II adalah 72,9 dan 79,6. Ketuntasan belajar klasikal meningkat sebesar yakni $50 \%$ pada siklus 2 .

Berdasarkan penjelasan pembelajaran Bahasa Indonesia dengan menerapkan metode Quantum Writing yang dilakukan pada 2 pertemuan yang dilaksanakan selama tindakan siklus I. Skor rata-rata aktivitas guru sebesar 27,5 dan berada dalam kategori cukup.

Kelemahan-kelemahan yang terdapat pada siklus I merupakan acuan perbaikan pada siklus II sehingga pembelajaran yang akan dilaksanakan dalam penelitian ini dapat mencapai keberhasilan. Setelah melakukan refleksi terhadap pelaksanaan siklus I, dan melakukan perbaikan-perbaikan dalam pembelajaran diperoleh hasil dengan skor 34 dengan kategori baik.

Berdasarkan data di atas dapat dijelaskan bahwa dengan metode Quantum Writing dalam melaksanakan proses pembelajaran telah meningkat. Hal ini terlihat pada perolehan rata-rata skor mengalami peningkatan dari 27,5 dengan kategori cukup meningkat menjadi 34 dengan kategori baik, sehingga dapat diartikan bahwa kualitas proses pembelajaran sudah meningkat.

Peningkatan tersebut tidak terlepas dari usaha guru dalam memperbaiki kelemahan-kelemahan yang terjadi pada siklus I. Pada siklus II ini guru sudah baik mengarahkan dan memberikan pertanyaan kepada siswa memberikan apersepsi pada saat kegiatan membuka pelajaran. Peningkatan ini juga berkaitan erat dengan upaya guru dalam menjelaskan kepada siswa tentang unsurunsur dan hal-hal yang perlu diperhatikan dalam surat lamaran pekerjaan. Mengusahakan perbaikan pada saat menyampaikan tujuan pembelajaran. Peningkatan ini juga berkaitan dengan upaya guru dalam membimbing memperbaiki 
pilihan kata, kalimat, dan ejaan. Hal ini sesuai dengan pendapat Bobbi DePoter dan Hernacki Mike mengungkapkan bahwa pada tahap penyuntingan akan diperbaiki semua kesalahan isi, pilihan kata, kalimat, paragraf, dan ejaan.

Peningkatan ini juga berkaitan dengan upaya guru dalam mengusahakan perbaikan pada saat guru menjelaskan langkah-langkah metode Quantum Writing yang akan diterapkan dalam menulis surat lamaran pekerjaan. Peningkatan ini juga berkaitan dengan upaya guru dalam mengawali pelajaran dengan memberikan motivasi siswa. Aktivitas guru yang baik di atas dapat berdampak pda peningkatan perilaku yang baik sehingga siswa merasa dilibatkan dalam pembelajaran. Peningkatan aktivitas guru siklus I dan siklus II ini dapat dilihat pada siklus I diperoleh rata-rata skor 27,5 dan meningkat menjadi 34 pada siklus II.

Berdasarkan data pengamat pada siklus I skor rata-rata aktivitas siswa sebesar 29 dan berada pada kategori cukup. Keunggulan pada aktivitas siswa siklus I antara lain siswa menulis surat lamaran pekerjaan berdasarkan iklan dengan baik, siswa menulis hasil penyuntingannya dengan baik, siswa mendengarkan musik pengiring belajar dengan baik, dan siswa merayakan pembelajaran bernyanyi bersama dengan antusias.

Keunggulan-keunggulan pada siklus I ini akan dipertahankan pada siklus II. Sementara itu aspek yang menjadi kelemahan pada suiklus I ini merupakan acuan untuk perbaikan pada siklus II agar pembelajaran pada penelitian dapat mencapai suatu keberhasilan. Berdasarkan pengamatan aktivitas siswa siklus II terdapat peningkatan skor aktifitas yaitu 32 dan berada pada kategori baik. Hal ini tidak lepas dari usaha dalam memperbaiki kelemahan yang ada pada siklus I.

Keberhasilan ini diantaranya nampak dari keberhasilan guru dalam mengupayakan agar siswa benar-benar maksimal dalam menyimak topik dan tujuan pembelajaran yang diberikan oleh guru. Hasil penelitian menunjukkkan bahwa terdapat perbedaan yang bearti antara tujuan pembelajaran yang disampaikan kepada siswa dengan yang tidak, dengan mengetahui tujuan pembelajaran yang ingin dicapai siswa akan lebih fokus pada kegiatan yang dilakukannya.

Pada siklus II ini juga siswa sudah siap memulai pembelajaran dengan baik. Siswa terlihat semangat, antusias dan dalam keadaan tenang untuk memulai pembelajaran. Perbaikan selanjutnya yaitu siswa sudah maksimal dalam memperhatikan penjelasan dari guru tentang menulis surat lamaran pekerjaan. Siswa membaca dan mengoreksi hasil tulisan temannya dengan seruis, siswa bisa memperbaiki isi, paragraf tulisannya masing-masing, siswa bisa memperbaiki tulisan masing-masing.

Siswa telah mengerti ketika memperbaiki pilihan kata, kalimat, dan ejaan, keseluruhan siswa menulis kembali hasil dari penyuntingan, siswa masih ragu menyimpulkan pembelajaran, siswa hanya memeriksa hasil dari tulisannya. Perbaikan selanjutnya yaitu siswa sudah maksimal menulis surat lamaran pekerjaan belum sesuai dengan isi, pilihan kata, kalimat, paragraf dan ejaan. Keberhasilan pembelajaran siklus II juga erat kaitannya dengan sudah baiknya siswa dalam merespon pemantapan materi yang diberikan oleh guru. Siswa sudah terlibat aktif pada saat pemantapan materi dari guru. Pemantapan materi juga sangat berpengaruh pada tujuan dan hasil belajar siswa. Pada siklus II ini siswa juga sudah maksimal dalam mendapatkan penguatan dan reward dari guru. Siswa yang bisa menjawab pertanyaan dan berpendapat dengan aktif dalam pembelajaran mendapat pujian dan siswa yang belum berhasil diberikan penguatan dan motivasi supaya aktif dalam kegiatan pembelajaran. Sehingga pembelajaran pada siklus II ini terasa lebih hangat dan antusias dari guru terhadap jawaban siswa, punya arti penting dalam meningkatkan partisipasi siswa dalam pembelajaran. Untuk itu guru perlu memberikan variasi dalam pemberian penguatan baik verbal maupun nonverbal. 


\section{KESIMPULAN DAN SARAN Kesimpulan}

Berdasarkan hasil penelitian dari siklus I dan II, dapat disimpulkan bahwa pembelajaran dengan metode Quantum Writing dapat meningkatkan kemampuan menulis surat lamaran pekerjaan siswa Kelas XII Mia 1 SMAN 1 MENJALIN Kabupaten Landak tahun ajaran 2018/2019. Peningkatan nilai diketahui dari nilai rata-rata pada siklus I yaitu 72,9 dan pada siklus II mengalami peningkatan sebesar $67 \%$ sehingga menjadi 79,6. Metode Quantum Writing ini juga dapat meningkatkan jumlah siswa yang tuntas belajar. Pada siklus I sebesar 50\% dan pada siklus II meningkat menjadi $75 \%$. mengalami peningkatan $25 \%$. Penerapan metode Quantum Writing. dapat meningkatkan kualitas proses menulis surat lamaran pekerjaan siswa di Kelas XII Mia 1 SMAN 1 MENJALIN Kabupaten Landak yaitu: (a) Meningkatkan kualitas aktivitas guru, peningkatan ini ditunjukkan dengan perolehan skor 27,5 dengan kriteria cukup pada siklus I dan meningkat 34 dengan kriteria baik pada siklus II. (b) Kualitas aktivitas siswa, peningkatan ini ditunjukkan dengan perolehan skor 29 dengan kriteria cukup pada siklus I dan meningkat menjadi 32 dengan kriteria baik pada siklus II.

\section{Saran}

Disarankan kepada guru untuk dapat mencoba menerapkan Metode Quantum Writing pada mata pelajaran yang lain agar dapat memberikan variatif baru dalam proses pembelajaran sebagai upaya untuk tercapainya tujuan pembelajaran yang diharapkan. Disarankan juga kepada guru dalam melaksanakan pembelajaran dengan menerapkan metode Quantum Writing terlebih dahulu menentukan materi yang sesuai untuk dilaksanakan karena tidak semua materi pembelajaran dapat dilakukan dengan menerapkan metode Quantum Writing. Bagi peneliti lain disarankan agar dilakukan penelitian lebih lanjut mengenai pembelajaran dengan menerapkan metode Quantum Writing Peneliti mengemukakan masih terdapat beberapa kekurangan dalam penelitian ini, diharapkan bagi peneliti lain kekurangan ini nantinya dapat dijadikan bahan rujukan untuk melakukan penelitian selanjutnya. Kekurangan itu diantaranya guru kurang maksimal dalam mengkondisikan kelas agar siap belajar, guru kurang maksimal dalam memberikan motivasi pada siswa untuk lebih aktif dalam kegiatan menulis surat lamaran pekerjaan yang dilaksanakan pada proses pembelajaran. Selanjutnya guru kurang maksimal dalam membimbing siswa menyimpulkan materi pembelajaran sehingga siswa kurang memahami kesimpulan materi yang telah dipelajari.

\section{DAFTAR PUSTAKA}

Arikunto, Suharsimi dkk. (2006). Penelitian Tindakan Kelas. Jakarta: Bumi Aksara.

Bobbi. DePorter . (2009).Quantum Writer Menulis Dengan Mudah, Fun, dan Hasil Memuaskan. Jakarta: Kaifa. 2010. Quantum Learning. Bandung: Kaifa.

Caca, Sudarsa dkk. 1992. Surat Menyurat Dalam Bahasa Indonesia. Jakarta: Pusat Pembinaan dan Pengembangan Bahasa.

Ferdiansyah, dan Abitur A. P. 2007. Mari Membuat Surat. Pontianak: Wpp.

Hernowo. 2003. Quantum Writing. Bandung: $\mathrm{MlC}$.

Nurgiyantoro, Burhan. 2001. Penilaian dalam Pengajaran Bahasa dan Sastra Indonesia. Yogyakarta: BPFE.

Sagala, S. 2003. Konsep dan Makna Pembelajaran: Untuk Membantu Memecahkan Problematika Belajar dan Mengajar. Bandung: Alfabeta.

Soewito, dkk 1980. Surat Menyurat Indonesia. Jakarta: Departemen Pendidikan dan kebudayaan.

Subagyo Heni.1997. Surat Menyurat. Surabaya: Amelia Surabaya.

Sudjana, Nana. 2006. Penilaian Hasil Proses Belajar Mengajar. Bandung: Remaja Rosdakarya.

Sukino. 2010. Menulis itu Mudah. Menulis itu Mudah. Yogyakarta: Pustaka Populer LKIS. 
Surakhmad, W. 1979. Metodologi Pengajaran Nasional. Bandung: Jemmars.

Susetyo. 2009. Menulis Akademik. Bengkulu: FKIP UNIB.
Suyatno. 2004. Teknik Pembelajaran Bahasa dan Sastra. Surabaya: SIC.

Tarigan Henry Guntur. 1994. Menulis Sebagai Suatu Keterampilan Berbahasa. Bandung: Angkasa. 